\title{
Enhanced anti-inflammatory effects of DHA and quercetin in lipopolysaccharide-induced RAW264.7 macrophages by inhibiting NF- $\kappa B$ and MAPK activation
}

\author{
TIAN-LEI SI ${ }^{1,2}$, QI LIU ${ }^{1,2}$, YU-FEI REN ${ }^{3}$, HUI LI $^{1}$, XIAO-YUN XU ${ }^{1,2}$, ER-HU LI $^{1,2}$, \\ SI-YI PAN ${ }^{1,2}$, JIU-LIANG ZHANG ${ }^{1,2}$ and KE-XING WANG ${ }^{1,2}$ \\ ${ }^{1}$ College of Food Science and Technology; ${ }^{2}$ Key Laboratory of Environment Correlative Dietology, Ministry of Education, \\ Huazhong Agricultural University, Wuhan, Hubei 430070; ${ }^{3}$ National Engineering Research Center For Wheaten Food, \\ Henan Xingtai S\&T Industry Co., Ltd., Zhengzhou, Henan 450007, P.R. China
}

Received June 25, 2015; Accepted March 21, 2016

DOI: $10.3892 / \mathrm{mmr} .2016 .5259$

\begin{abstract}
The aim of the present study was to investigate the anti-inflammatory effects of docosahexaenoic acid (DHA) + quercetin (QE) used in combination. DHA and $\mathrm{QE}$ are natural compounds derived from various foods and have been demonstrated to exert anti-inflammatory effects The protein mRNA expression involved in the nuclear factor (NF) $-\kappa B$ and mitogen-activated protein kinase (MAPK) signalling pathway was analyzed by western blot analysis and reverse transcription-polymerase chain reaction methods respectively, other cytokines were detected by an enzyme-linked immunosorbent assay kit. The results of the present study demonstrated that combined treatment of lipopolysaccharide (LPS)-stimulated RAW264.7 cells with $\mathrm{DHA}+\mathrm{QE}$ decreased the levels of pro-inflammatory mediators to a greater extent than $\mathrm{QE}$ or DHA alone. Additionally, DHA + QE synergistically suppressed nitric oxide, prostaglandin E2 and cyclooxygenase-2 levels. Molecular-level studies indicated that the DHA + QE combination can significantly inhibit the mRNA expression of $N F-\kappa B$ subunits $p 50$ and p65, extracellular signal-regulated kinase (ERK) $1 / 2$ and c-JUN N-terminal kinase (JNK) 1/2, which suggests that the
\end{abstract}

Correspondence to: Dr Er-Hu Li, College of Food Science and Technology, Huazhong Agricultural University, 1 Shizishan Road, Wuhan, Hubei 430070, P.R. China

E-mail: erhuli@mail.hzau.edu.cn

Abbreviations: DHA, docosahexaenoic acid; COX-2, cyclooxygenase-2; ERK, extracellular signal-regulated kinase;

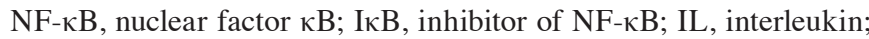
iNOS, inducible nitric oxide synthase; JNK, c-JUN N-terminal kinase; LPS, lipopolysaccharide; MAPK, mitogen-activated protein kinase; NO, nitric oxide; NOP, NO production

Key words: docosahexaenoic acid, quercetin, inflammatory cytokines, nitric oxide, nuclear factor- $\kappa \mathrm{B}$, mitogen-activated protein kinase
$\mathrm{NF}-\kappa \mathrm{B}$ signalling pathway is involved in the synergistic effects observed. Furthermore, western blot analysis demonstrated that DHA + QE synergistically inhibit the phosphorylation of p50, p65, ERK1/2 and JNK1/2. This finding indicates that the enhanced anti-inflammatory effects of the combined compounds are achieved by suppressing NF- $\kappa \mathrm{B}$ and MAPK signalling in LPS-stimulated RAW264.7 cells. The results of the present study suggest that DHA and QE in combination may be utilized as potent anti-inflammatory compounds, with potential preventative or palliative effects on obesity, atherosclerosis and cardiovascular diseases.

\section{Introduction}

Inflammation is associated with a variety of progressive diseases, including cancer, cardiovascular disease, obesity and metabolic disorders, thus, to a certain extent, eliminating or preventing inflammation is important to maintain health (1). Inflammatory cells, including macrophages, mononuclear phagocytes, eosinophils and neutrophils, are activated during inflammation, and secrete high levels of nitric oxide (NO), prostaglandin E2 (PGE2) and cytokines, such as interleukin (IL)-1 $\beta$, IL- 6 and tumour necrosis factor- $\alpha$ (TNF- $\alpha$ ), resulting in cell and tissue damage (2,3). Previous studies have demonstrated that macrophages perform an important function in initiating and developing the inflammatory process, as well as stimulating the excess production of pro-inflammatory mediators. Activated macrophages produce a series of pro-inflammatory mediators, including NO, PGE2, IL-1 $\beta$, IL-6 and TNF- $\alpha$, which are important during the development of various chronic diseases $(3,4)$. NO and PGE2 are important pro-inflammatory mediators regulated by inducible nitric oxide synthase (iNOS) and cyclooxygenase-2 (COX-2), respectively. The expression of pro-inflammatory mediators, including iNOS, COX-2, TNF- $\alpha$, IL-1 $\beta$ and IL-6, is regulated by the transcription factor nuclear factor- $\kappa \mathrm{B}(\mathrm{NF}-\kappa \mathrm{B})(5,6)$. Canonical $\mathrm{NF}-\kappa \mathrm{B}$ exists in the cytoplasm as an inactive dimeric protein composed of two subunits (P50 and P65) and is bound to inhibitor of $\mathrm{NF}-\kappa \mathrm{B}(\mathrm{I} \kappa \mathrm{B})$ protein. When stimulated by other endogenous inducers, including IL- $1 \beta$ and TNF- $\alpha$, and 
exogenetic factors, such as lipopolysaccharide (LPS), I $\kappa$ B is phosphorylated and degraded. The released NF- $\kappa \mathrm{B}$ dimer can then be translocated from the cytoplasm to the nucleus when activated by p65 phosphorylation and regulate target gene transcription (7). Propagation of the inflammatory process is regulated by multiple mechanisms. Upon LPS stimulation of macrophages, the endotoxin (LPS) reaches specific toll-like receptors on the cell membrane, inducing complex signalling cascades and stimulation of the three mitogen-activated protein kinase (MAPK) signalling pathways. The MAPK pathway is one of the most widely studied intracellular signalling cascades. The pathway is composed of p38MAPK, extracellular signal-regulated kinase $1 / 2$ (ERK1/2) and c-JUN $\mathrm{N}$-terminal kinase (JNK), all of which are involved in $\mathrm{NF}-\kappa \mathrm{B}$ activation $(7,8)$. Thus, inhibiting the MAPK and NF- $\kappa \mathrm{B}$ pathways to reduce the production of pro-inflammatory cytokines is crucial for suppressing the inflammatory response.

Several food-derived compounds have been demonstrated to decrease inflammation associated with certain diseases. Dietary antioxidants and flavonoids are abundant in fruits and vegetables, and have important functions as pharmacologically active compounds in Chinese herbs. The biological activities of these compounds includes antioxidant, anti-inflammatory, antiviral and anticarcinogenic effects $(9,10)$. These beneficial effects are partially due to the free radical scavenging ability of the molecules, which suppresses the production of inflammatory cytokines by interfering with intracellular signalling pathways and modulating gene expression $(11,12)$. Quercetin (QE) is a common flavonol present in a wide range of food resources, including fruits, vegetables, tea, nuts, wine and seeds. QE is a potent bioactive flavonoid with various beneficial effects on human health; it promotes free radical scavenging, and demonstrates strong antioxidant and anti-inflammatory activities (13-15). Other functional food components that can ameliorate inflammation include omega-3 long chain polyunsaturated fatty acids. Marine fish oil is a major source of eicosapentaenoic acid (EPA) and docosahexaenoic acid (DHA) (16). These molecules provide various positive benefits to human health, particularly in preventing cardiovascular and inflammatory diseases. QE and DHA are present in a variety of foods as natural compounds, and alternative DHA sources, including aquatic microbes or transgenic crops, have been used to address fish stock limitations and risks associated with ocean pollution (17). Thus, as these molecules are easily consumed as food ingredients or functional food supplements in combination, determining their synergistic, additive or antagonistic effects may be important for developing novel food products with beneficial effects on human health. The anti-inflammatory capacities of QE and DHA have been investigated individually but not in combination, and little is known regarding the combinational anti-inflammatory effects of these compounds in LPS-induced RAW264.7 murine macrophage cells. Several studies indicate that DHA is more potent than EPA in reducing IL- $1 \beta$ and IL-6 expression in LPS-activated macrophages (18). Thus, the anti-inflammatory effects of QE and DHA, in combination and separately, must be elucidated.

The present study aimed to assess whether QE and DHA treatment of RAW264.7 cells can modulate the expression levels of pro-inflammatory mediators (NO, iNOS, PGE2,
COX-2, IL-1 $\beta$, IL-6, TNF- $\alpha$ ) and key proteins (p50, p65, I $\mathrm{B}$, ERK, JNK, p38MAPK), as well as the phosphorylation levels of proteins involved in the NF- $\mathrm{KB}$ and MAPK signalling pathways. Additionally, the current study investigated the synergistic anti-inflammatory effects of QE and DHA on RAW264.7 cells stimulated with LPS to induce inflammatory responses.

\section{Materials and methods}

Reagents. DHA (D2534; $\geq 98 \%$ ), QE (Q4591; $\geq 98 \%$ ), dimethylsulphoxide (DMSO), LPS, Griess reagent, phosphate-buffered saline (PBS), 3-(4,5-dimethylthiazol-2-yl)-2,5-diphenyltertrazolium (MTT), sodium nitrite and radioimmunoprecipitation assay (RIPA) buffer were purchased from Sigma-Aldrich (St. Louis, MO, USA). Primary antibodies against iNOS (rabbit polyclonal antibody; 1:400 dilution; cat. no. ab3523) and COX-2 (rabbit polyclonal antibody, 1:200 dilution; cat. no. ab15191) were purchased from Abcam Trading Company (Shanghai, China). IкB (rabbit polyclonal antibody, 1:200 dilution; cat. no. sc847), phospho-(p-)-IкB (mouse monoclonal antibody, 1:200 dilution; cat. no. sc8404) were obtained from Santa Cruz Biotechnology, Inc. (Dallas, TX, USA). p-ERK (rabbit monoclonal antibody, 1:1,000 dilution; cat. no. 8544) and p-JNK (rabbit monoclonal antibody, 1:800 dilution; cat. no. 4668) were obtained from Cell Signaling Technology, Inc. (Danvers, MA, USA). p-p50 (rabbit polyclonal antibody, 1:700 dilution; cat. no. BS4131), p-p38 (rabbit polyclonal antibody, 1:600 dilution; cat. no. BS4635) and p-p65 (rabbit polyclonal antibody, 1:700 dilution; cat. no. BS3556) were purchased from Bioworld Technology, Co., Ltd. (Nanjing, China). and horseradish peroxidase (HRP)-conjugated secondary antibodies were purchased from Cell Signalling Technology, Inc. (Danvers, MA, USA). Enzyme-linked immunosorbent assay (ELISA) kits for IL-1 $\beta$, IL-6, TNF- $\alpha$ and PGE2 were obtained from Nanjing Jiancheng Bioengineering Institute (Nanjing, China).

Cell culture. RAW264.7 murine macrophage cells (Type Culture Collection of the Chinese Academy of Sciences, Shanghai, China) were cultured in Dulbecco's modified Eagle's medium (DMEM; Gibco; Thermo Fisher Scientific, Inc., Waltham, MA, USA) with $10 \%$ foetal bovine serum (FBS) (Gibco; Thermo Fisher Scientific, Inc.), 2 mM D-glutamine (Shanghai Hanhong Chemical Co., Ltd., Shanghai, China) and antibiotics (100 U/ml penicillin and $100 \mu \mathrm{g} / \mathrm{ml}$ streptomycin) (Dingguo Biotechnology Co., Ltd., Wuhan, China) at $37^{\circ} \mathrm{C}$ and $5 \% \mathrm{CO}_{2}$ in a humidified incubator.

Cell viability assay. Cell viability was evaluated using an MTT assay. RAW264.7 cells were seeded in 24-well plates at a density of $1 \times 10^{5}$ cells/well and incubated at $37^{\circ} \mathrm{C}$ for $24 \mathrm{~h}$. The cells were treated with DHA (30 and $60 \mu \mathrm{M}), \mathrm{QE}(20$, 40 and $60 \mu \mathrm{M})$ or DHA + QE and then stimulated with LPS $(100 \mathrm{ng} / \mathrm{ml})$ in medium or left untreated at $37^{\circ} \mathrm{C}$ for $24 \mathrm{~h}$. MTT solution $(\sim 1 \mathrm{ml}, 5 \mathrm{mg} / \mathrm{ml})$ was added to each well and the plates were incubated at $37^{\circ} \mathrm{C}$ for $4 \mathrm{~h}$. Blue formazan crystals were dissolved in DMSO and the absorbance of the solution was measured at $570 \mathrm{~nm}$ using a microplate reader (Multiskan FC; Thermo Fisher Scientific, Inc.). 
Nitrite assay. NO production (NOP) was measured as nitrite by Griess reagent to evaluate the anti-inflammatory effects of DHA and QE separately or in combination. Five conditions were examined, as follows: Negative control $\left(\mathrm{C}^{-}\right)$, medium only (DMEM, 10\% FBS, 2 mM D-glutamine and antibiotics); positive control $\left(\mathrm{C}^{+}\right), 100 \mathrm{ng} / \mathrm{ml}$ LPS; LPS plus DHA treatment (30 and $60 \mu \mathrm{M})$; LPS plus QE treatment (20, 40 and $60 \mu \mathrm{M})$; and LPS plus DHA + QE treatment. The cells were cultured in 24 -well plates at $2 \times 10^{5}$ cells/well and grown to $80-90 \%$ confluence. The medium was replaced with colourless serum-free DMEM medium with antibiotics. The cells were then stimulated with LPS (100 ng/ml), incubated with or without DHA, QE or $\mathrm{DHA}+\mathrm{QE}$, and then cultured at $37^{\circ} \mathrm{C}$ for $24 \mathrm{~h}$. The supernatant (100 $\mu \mathrm{l}$ ) was collected and mixed with $100 \mu \mathrm{l}$ Griess reagent to produce a final stable purple product. The absorbance of the mixture was quantified by a microplate reader at $540 \mathrm{~nm}$. Biological and technical replicates were performed for all measurements in triplicate. A standard sodium nitrite curve was established to determine nitrite levels.

Measurement of pro-inflammatory cytokine and PGE2 protein concentration levels. RAW264.7 cells were seeded in 24-well plates at a density of $1 \times 10^{5}$ cells/well and grown to $80-90 \%$ confluence. The medium was replaced with colorless serum-free DMEM medium with antibiotics. The cells were then treated with one of the following: Medium only (with vehicle); $100 \mathrm{ng} / \mathrm{ml}$ LPS; LPS plus $20 \mu \mathrm{M}$ QE; LPS plus $30 \mu \mathrm{M}$ DHA; or LPS plus QE + DHA. The supernatant was collected after $24 \mathrm{~h}$ of treatment to evaluate IL-1 $\beta$, IL-6, TNF- $\alpha$ and PGE2 levels using ELISA kits, according to the manufacturer's protocol.

Measurement of protein expression in LPS-induced RAW264.7 cells by western blot analysis. Cells were washed with PBS then harvested and lysed in RIPA buffer (Beyotime Institute of Biotechnology, Shanghai, China), then $1 \mathrm{mM}$ PMSF (Beyotime Biotechnology Inc., Shanghai, China) was added into the lysate. The mixture was centrifuged at $4{ }^{\circ} \mathrm{C}$ and $1,4000 \mathrm{x}$ g for $5 \mathrm{~min}$, the supernatant was collected for the next step. The concentration of protein was quantified by a Bicinchoninic acid protein assay kit (Beyotime Institute of Biotechnology). Total cell proteins (20 $\mu \mathrm{g}$ RAW264.7 lysates) were separated by $10 \%$ sodium dodecyl sulfate-polyacrylamide gel (Thermo Fisher Scientific, Inc.) electrophoresis and transferred to polyvinylidene difluoride membranes (Merck Millipore, Darmstadt, Germany). The membranes were blocked in Tris-buffered saline-Tween 20 solution (Dingguo Biotechnology Co., Ltd.) containing 5\% non-fat dry milk and incubated with specific antibodies overnight at $4^{\circ} \mathrm{C}$. Protein bands were visualized using an enhanced chemiluminescent reagent (Thermo Fisher Scientific, Inc.) following incubation with HRP-conjugated secondary antibodies for $2 \mathrm{~h}$ at room temperature. The band intensity was quantified with BandScan 5.0 (Glyko, Novato, CA, USA). Values of each sample were normalized to the fraction of $\beta$-actin and all experiments were repeated 3 times.

Measurement of $I \kappa B, p 65, p 50$, ERK1/2, JNK and p38MAPK mRNA expression by semi-quantitative reverse transcription-polymerase chain reaction (RT-PCR). Total RNA was
Table I. Primers used to perform polymerase chain reaction.

Gene $\quad$ Primer (5'-3')

$\mathrm{I} \kappa \mathrm{B}$

Sense

Antisense

GAACCTGAGGACGAGGACGAT

p65

Sense

Antisense

GGGATGGCTACTATGAGGCTGACC

p50

Sense

Antisense

GTGATTTGTGCCAGCCAGGAAGC

p38

Sense

Antisense

GGGACCTAAAGCCCAGCAACCT

ERK

Sense

Antisense

CATGGAGACGGACCTTTACAAGC
CACAAGTGGTGTTCAGCAGGAGG

JNK

Sense

Antisense

TCTCCAGCACCCATACATCAACG

$\beta$-actin

Sense

Antisense

CACGATGGAGGGGCCGGACTCATC TAAAGACCTCTATGCCAACACAGT

$\mathrm{I} \kappa \mathrm{B}$, inhibitor of nuclear factor $\kappa \mathrm{B}$; ERK, extracellular signal-regulated kinase; JNK, c-JUN N-terminal kinase.

isolated from RAW264.7 cells using the Qiagen RNeasy kit (Qiagen, Inc., Valencia, CA, USA), according to the manufacturer's instructions. RNA samples $(4.2 \mu \mathrm{g})$ were treated with RNase-Free Recombinant DNase I (cat.no.\#2270A, Takara Bio Inc., Tokyo, Japan). cDNA was synthesized using the Primer Script RT reagent kit according to the manufacturer's instructions (Takara Co., Ltd., Tokyo, Japan). PCR was performed on the cDNA with the appropriate sense and antisense primers, as indicated in Table I (Nanjing Genscript Biotechnology Co., Ltd., Nanjing, China). Each reaction was performed in a total volume of $20 \mu \mathrm{l}$ containing $2 \mathrm{X} 10 \mu \mathrm{l}$ SYBR Green/Fluorescein qPCR Master mix (Fermentas; Thermo Fisher Scientific, Inc.), $4 \mu \mathrm{cDNA}$ and $0.2 \mu \mathrm{mol} / 1$ of each primer. PCR was conducted using an ABI, ViiA7 thermal cycler (Applied Biosystems; Thermo Fisher Scientific, Inc.). The cycling conditions are as follows: 1 cycle of $50^{\circ} \mathrm{C}$ for $2 \mathrm{~min}$; pre-denaturation at $95^{\circ} \mathrm{C}$ for $10 \mathrm{~min}$; 40 cycles of amplification denaturation at $95^{\circ} \mathrm{C}$ for $30 \mathrm{sec}$, annealing at $60^{\circ} \mathrm{C}$ for $30 \mathrm{sec}$ and elongation at $72^{\circ} \mathrm{C}$ for $12 \mathrm{sec}$, followed by a final extension (denaturation at $95^{\circ} \mathrm{C}$ for $5 \mathrm{sec}$, annealing at $65^{\circ} \mathrm{C}$ for $1 \mathrm{~min}$, elongation at $97^{\circ} \mathrm{C}$ for $5 \mathrm{sec}$, and $50^{\circ} \mathrm{C}$ for cooling) in order to generate a melting curve. The PCR products were separated using electrophoresis on 1.4\% agarose gels (Dingguo Biotechnology Co., Ltd.) and stained with ethidium bromide (Dingguo Biotechnology Co., Ltd.) for visualization. The relative expression of each gene was calculated by the comparative $\mathrm{Cq}$ (cycle quantification or $\Delta \Delta \mathrm{Cq}$ ) method. The gene expression levels were normalized 


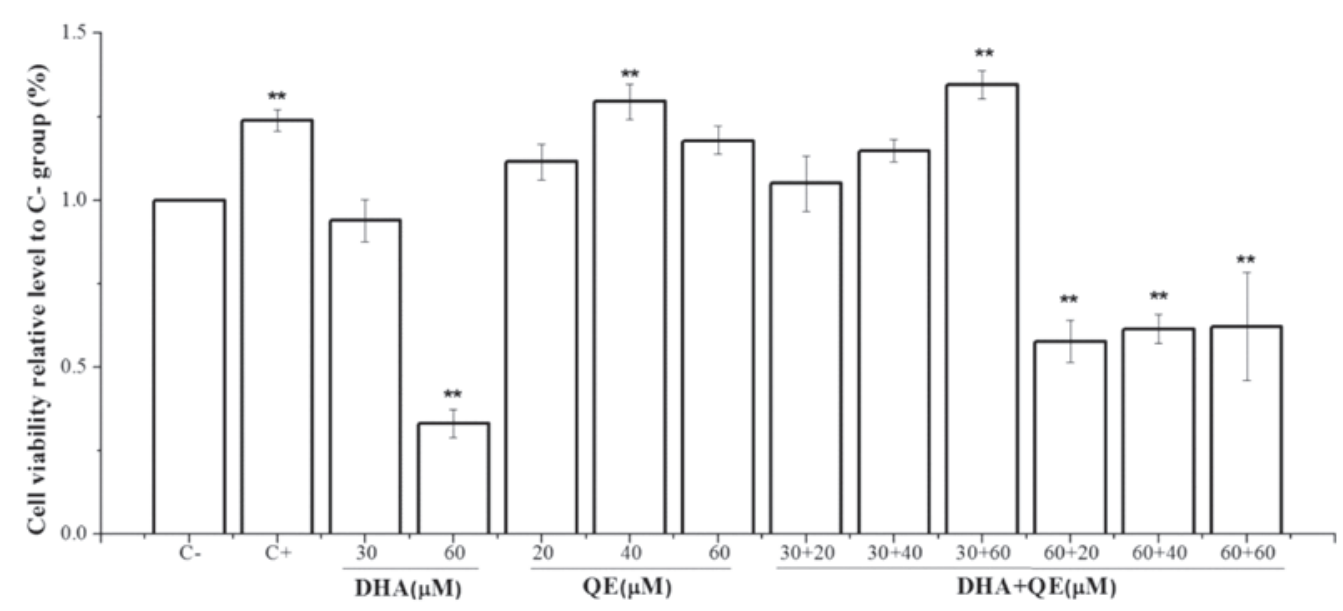

Figure 1. Cell viability of RAW264.7 cells following treatment with DHA and/or QE. RAW264.7 cells were seeded in 24-well plates at a density of $1 \times 10^{5}$ cells/well and incubated at $37^{\circ} \mathrm{C}$ for $24 \mathrm{~h}$. The cells were stimulated with or without lipopolysaccharide $(100 \mathrm{ng} / \mathrm{ml})$ then treated with DHA $(30 \mathrm{and}$ $60 \mu \mathrm{M}), \mathrm{QE}(20,40$ and $60 \mu \mathrm{M})$ or DHA $+\mathrm{QE}$ at $37^{\circ} \mathrm{C}$ for $24 \mathrm{~h}$. Results are expressed as the cell viability percentage normalized to the $\mathrm{C}^{-}$group. Values are presented as the mean \pm standard deviation of biological and technical triplicates. ${ }^{* *} \mathrm{P}<0.01$ vs. $\mathrm{C}^{-}$group. $\mathrm{C}^{-}$, negative control; $\mathrm{C}^{+}$, positive control; DHA, docosahexaenoic acid; QE, quercetin.

to the reference gene ( $\beta$-actin). Oligo dT primers, reverse transcriptase, RT buffer and dNTPs used for reverse transcription (or the kit used).

Calculating the potentiating effects of $Q E$ and DHA in combination. Enhancements of the effects of QE and DHA in combination were evaluated according to the following previously described method $(16,19)$. Using NOP as an example, the maximum inhibitory effects of compound $\mathrm{A}$ and $\mathrm{B}$ alone in a medium (expressed as percentages) are calculated as follows: $\mathrm{E}_{(\mathrm{A})}=\% \mathrm{NOP}$ in $\mathrm{C}^{+}$group - \%NOP of compound $\mathrm{A}+$ standard error of the mean (SEM); $\mathrm{E}_{(\mathrm{B})}=\% \mathrm{NOP}$ in $\mathrm{C}^{+}$group - \%NOP of compound $\mathrm{B}+\mathrm{SEM}$. The minimum inhibitory effects of the compounds in combination in medium is calculated as follows: $\mathrm{E}_{(\mathrm{AB})}=\% \mathrm{NOP}$ in $\mathrm{C}^{+}$group - \%NOP of compound $\mathrm{A}$ and $\mathrm{B}$ - SEM. Enhanced anti-inflammatory effects are observed when $\mathrm{E}_{(\mathrm{AB})} \geq \mathrm{E}_{(\mathrm{A})}+\mathrm{E}_{(\mathrm{B})}$. Both $\mathrm{QE}$ and DHA must have significant individual NOPs compared with the NOP obtained when QE and DHA are combined. If either QE or DHA fails to fulfil this criterion, the compounds are considered to have no effect when combined. These criteria were also applied to determine effects on protein phosphorylation and expression.

The Bliss independence model was used to evaluate whether the enhanced effects in this study can be considered synergistic, additive or antagonistic (16). This model is one of the most widely adopted, recommended and accepted models for defining drug interactions and is, thus, suitable for the present study. The model equation is $\mathrm{E}_{(\mathrm{AB})}=\mathrm{E}_{(\mathrm{A})} \times \mathrm{E}_{(\mathrm{B})}$, where $\mathrm{E}_{(\mathrm{AB})}$ is the effect of the compounds in combination, and $\mathrm{E}_{(\mathrm{A})}$ and $\mathrm{E}_{(\mathrm{B})}$ represent the individual effects of compounds $\mathrm{A}$ and $\mathrm{B}$, respectively. All equation results are expressed in fractions. $\mathrm{E}_{(\mathrm{AB})}<\mathrm{E}_{(\mathrm{A})} \times \mathrm{E}_{(\mathrm{B})}, \mathrm{E}_{(\mathrm{AB})}=\mathrm{E}_{(\mathrm{A})} \times \mathrm{E}_{(\mathrm{B})}$ and $\mathrm{E}_{(\mathrm{AB})}>\mathrm{E}_{(\mathrm{A})} \times \mathrm{E}_{(\mathrm{B})}$ indicate synergistic, additive and antagonistic effects, respectively.

Statistical analysis. Results are expressed as mean \pm standard deviation, and data were analyzed by one-way analysis of variance followed by a Dunnett's test to evaluate statistical differences between groups using SPSS 16.0 statistical software (SPSS, Inc., Chicago, IL, USA). P $<0.05$ was considered to indicate a statistically significant difference.

\section{Results}

Cytotoxicity of DHA and QE on RAW264.7 cells. An MTT assay was performed to evaluate DHA and QE toxicity on RAW264.7 cells. The DMSO concentration was controlled within $0.01 \%$ in the culture medium to allow adequate dissolution and did not affect the anti-inflammatory effects of DHA, QE and DHA + QE. The MTT assay (Fig. 1) indicated that the viability of RAW264.7 macrophages was not significantly changed under experimental conditions of $30 \mu \mathrm{M} \mathrm{DHA}, 20 \mu \mathrm{M}$ $\mathrm{QE}$ or $30 \mu \mathrm{M}$ DHA $+20 \mu \mathrm{M}$ QE compared with the $\mathrm{C}^{-}$group. However, the higher concentration of DHA $(60 \mu \mathrm{M})$ and its combination with QE, as well as $40 \mu \mathrm{M} \mathrm{QE}$ alone, significantly decreased cell viability compared with the $\mathrm{C}^{-}$group $(\mathrm{P}<0.01)$.

Effects of QE and DHA on NOP and iNOS protein expression in LPS-stimulated RAW 264.7 cells. LPS, the major cell wall component in gram-negative bacteria, can trigger inflammatory responses in macrophages. The levels of several biomarkers, including $\mathrm{NO}$, can be used to evaluate the LPS-induced inflammatory response. RAW264.7 cells were stimulated with LPS then incubated with various concentrations of DHA (30 and $60 \mu \mathrm{M})$ and QE (20, 40 and $60 \mu \mathrm{M})$ alone or in combination for $24 \mathrm{~h}$ to measure the effects of $\mathrm{QE}$ and DHA on NOP suppression. The supernatant was collected to determine the NOP levels.

Data for each group are calculated as the NO expression level versus that of the $\mathrm{C}^{+}$group. Then the $\mathrm{C}^{+}$group was set to 1 , and the expression of each group was relative to that of the $\mathrm{C}^{+}$group. DHA ( $\left.30 \mu \mathrm{M}\right)$ treatment significantly suppressed NOP compared with the $\mathrm{C}^{+}$group (30.4\% NO reduction, $\mathrm{P}<0.05)$. QE $(20 \mu \mathrm{M})$ similarly inhibited NOP compared with the $\mathrm{C}^{+}$group $(25.5 \% \mathrm{NO}$ reduction, $\mathrm{P}<0.05)$. Combined treatment with the molecules at the aforementioned concentrations 
A

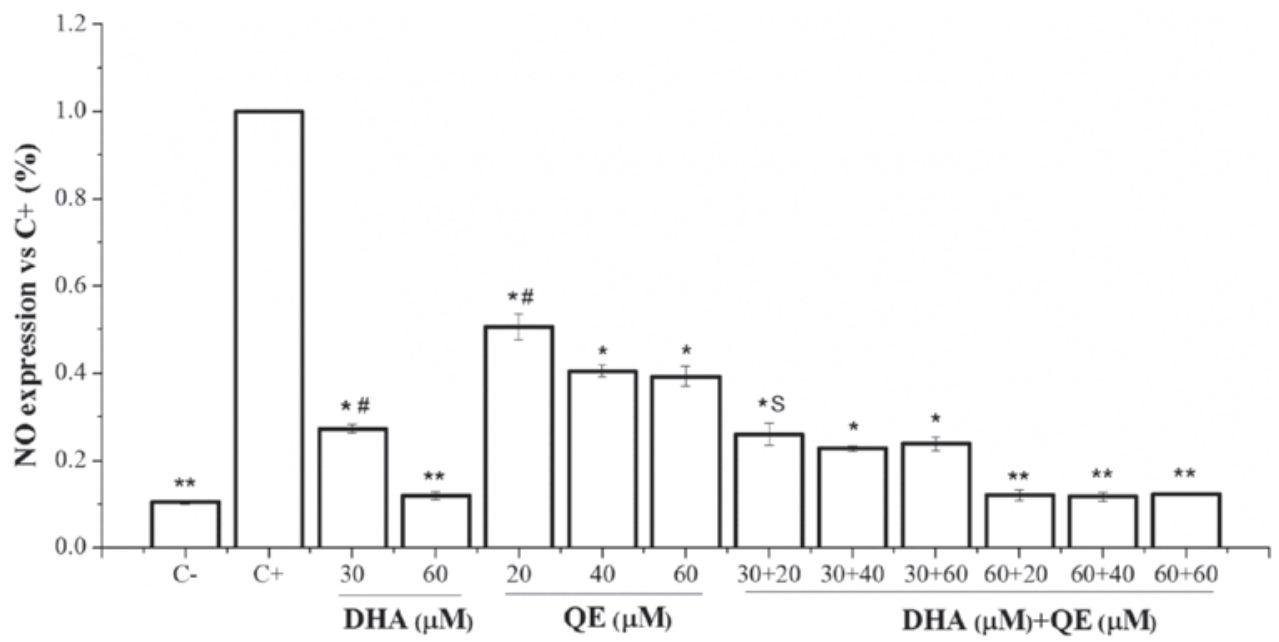

B
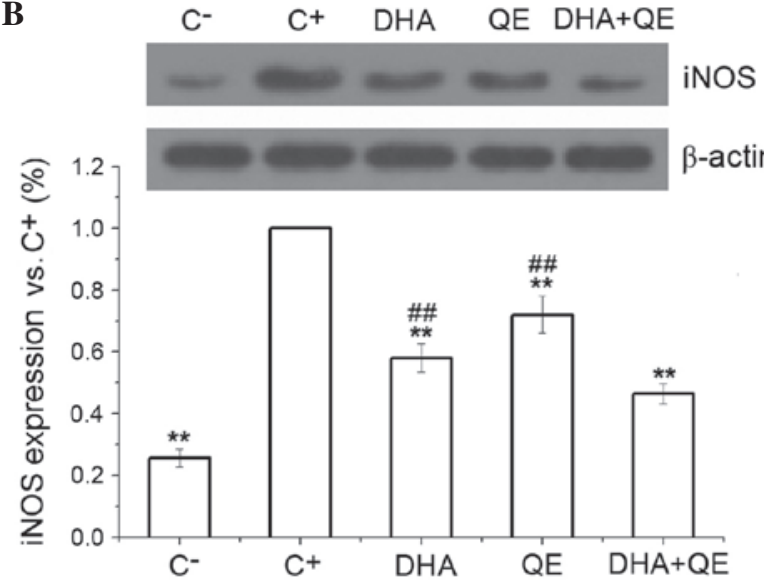

C
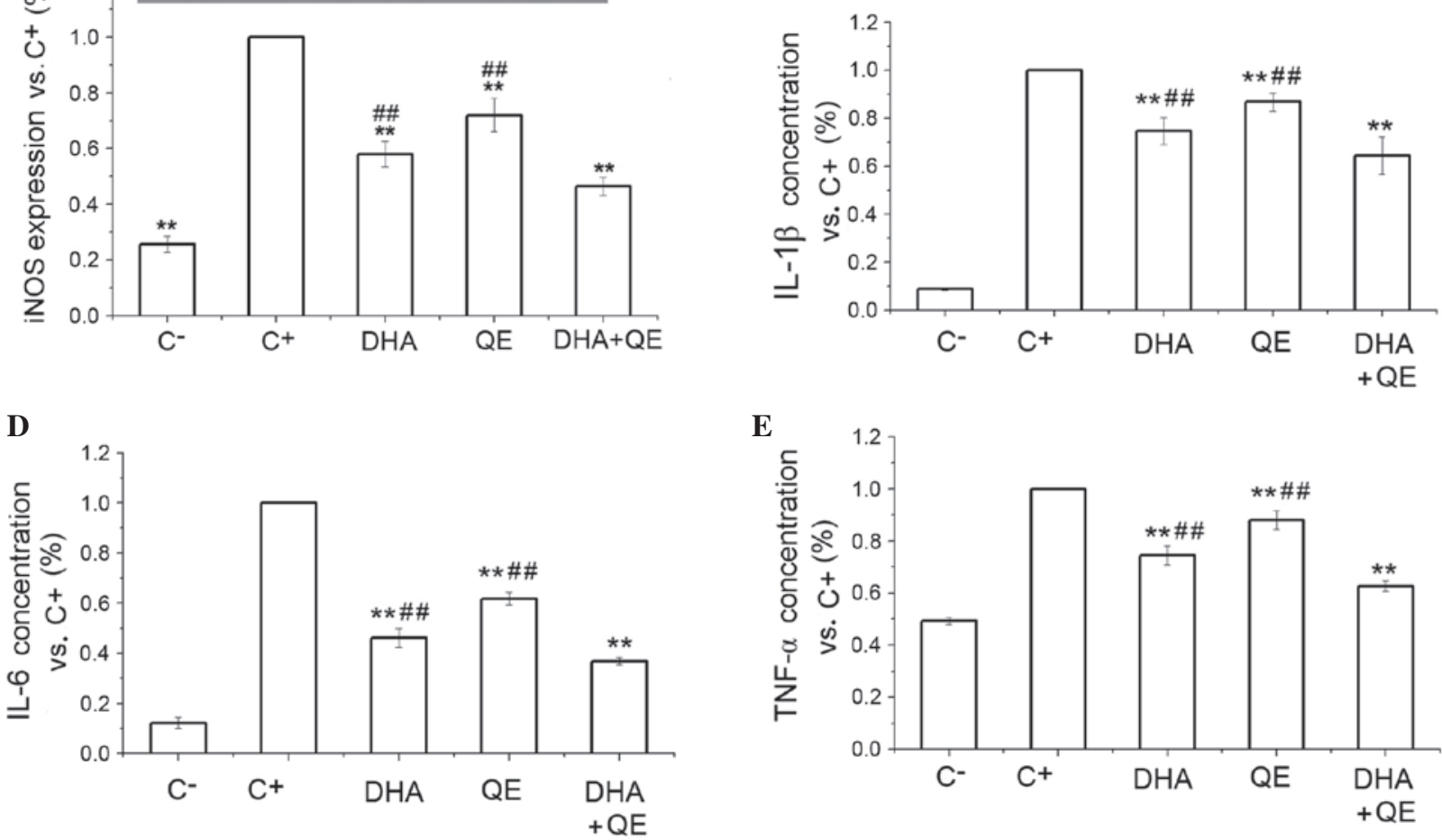

$\mathbf{E}$

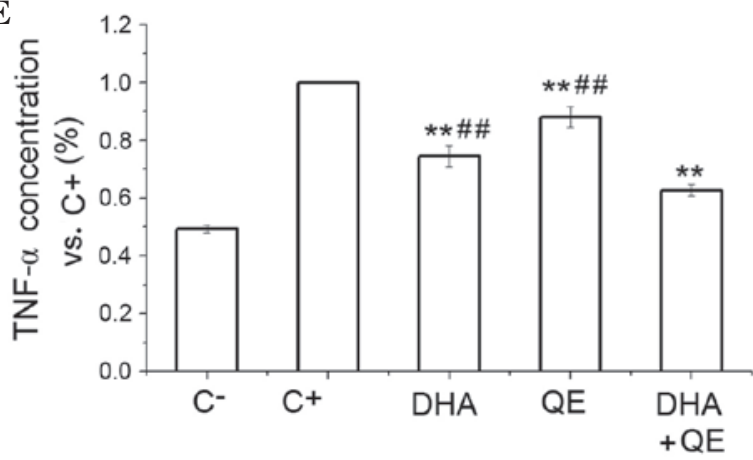

Figure 2. Inhibitory effects of DHA and QE on inflammatory mediators. (A) NO production was measured in lipopolysaccharide (LPS)-stimulated RAW264.7

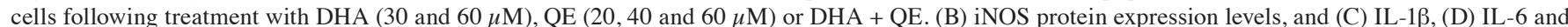
(E) TNF- $\alpha$ protein concentration levels were measured in LPS-stimulated RAW264.7 cells treated with DHA (30 $\mu$ M), QE (20 $\mu$ M) or DHA + QE. Results are expressed as percentage normalized to the $\mathrm{C}^{+}$group. Values are presented as the mean \pm standard deviation of biological and technical triplicates. ${ }^{*} \mathrm{P}<0.05$ and ${ }^{* *} \mathrm{P}<0.01$ vs. $\mathrm{C}^{+}$group. ${ }^{\#} \mathrm{P}<0.05$ and ${ }^{\# \#} \mathrm{P}<0.01$ vs. $\mathrm{DHA}+\mathrm{QE}$. Synergistic effects are indicated by the letter $\mathrm{S}$. NO, nitric oxide; $\mathrm{C}^{-}$, negative control; $\mathrm{C}^{+}$, positive control; DHA, docosahexaenoic acid; QE, quercetin; IL, interleukin; TNF- $\alpha$, tumour necrosis factor- $\alpha$.

exerted a stronger suppressive effect than either DHA or QE individually (61.6\% NO reduction) (Fig. 2A). The Bliss model, $\mathrm{E}_{(\mathrm{AB})}=\mathrm{E}_{(\mathrm{A})} \times \mathrm{E}_{(\mathrm{B})}$, demonstrated that the $\mathrm{E}_{(\mathrm{AB})}$ value (0.384) was less than $\mathrm{E}_{(\mathrm{A})} \times \mathrm{E}_{(\mathrm{B})}(0.519$; DHA $\mathrm{x} \mathrm{QE}=0.696 \times 0.745)$, indicating the synergistic effects of the two compounds. The higher concentration of DHA $(60 \mu \mathrm{M})$ and combination with QE demonstrated an even greater inhibitory effect on NOP, however, these concentrations reduced cell viability in the MTT assay (Fig. 1). Thus, the present study used the doses of $30 \mu \mathrm{M}$ DHA and $20 \mu \mathrm{M} \mathrm{QE}$ to examine their anti-inflammatory effect.

DHA + QE combination treatment exhibited statistically significant suppression of LPS-induced iNOS protein expression compared with the $\mathrm{C}^{+}$group and the individual drug treatments $(\mathrm{P}<0.01$; Fig. 2B). However, an antagonistic effect was detected using the Bliss model $\left[\mathrm{E}_{(\mathrm{AB})}=0.464 ; \mathrm{E}_{(\mathrm{A})}\right.$ $\left.x E_{(B)}=0.418\right](P=0.01 ;$ Fig. 2B). This effect may indicate that 
A

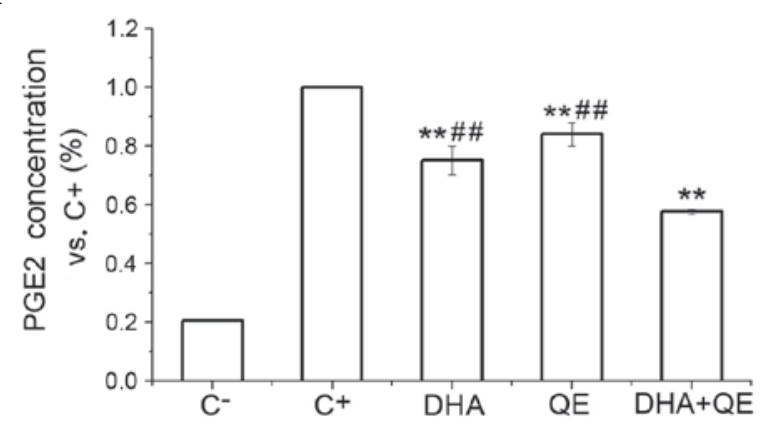

B

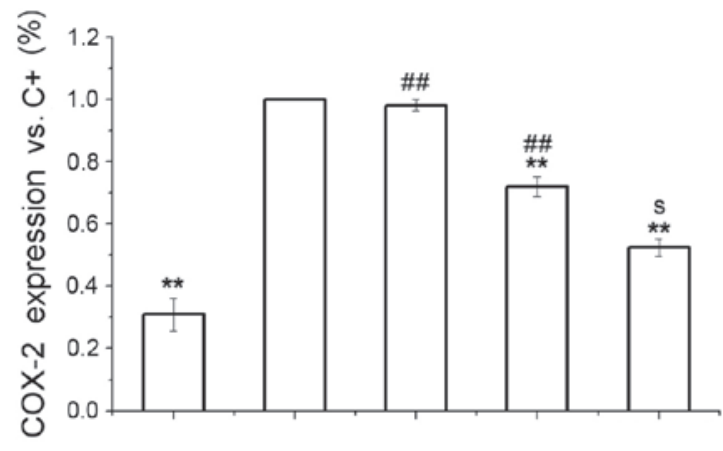

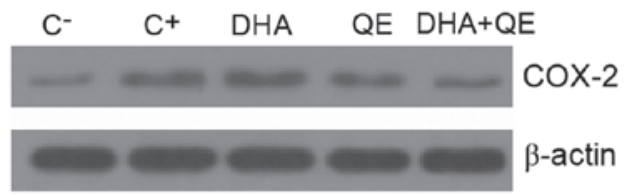

Figure 3. Effects of DHA and QE on iNOS and COX-2 expression in lipopolysaccharide (LPS)-induced RAW264.7 cells. RAW264.7 cells were stimulated with LPS $(100 \mathrm{ng} / \mathrm{ml})$ and incubated with DHA $(30 \mu \mathrm{M})$, QE $(20 \mu \mathrm{M})$ or DHA + QE for $24 \mathrm{~h}$. (A) PGE2 protein concentration was measured by enzyme-linked immunosorbent assay and (B) the protein levels of COX-2 were determined by western blot analysis. Results are expressed as percentages of PGE2 production/COX-2 levels normalized to the $\mathrm{C}^{+}$group. Values are presented as the mean \pm standard deviation of biological and technical triplicates. ${ }^{* *} \mathrm{P}<0.01$ vs. $\mathrm{C}^{+}$group. Synergistic effects are indicated by the letter $\mathrm{S} .{ }^{\# \#} \mathrm{P}<0.01$ vs. DHA + QE group. PGE2, prostaglandin E2; $\mathrm{C}^{-}$, negative control; $\mathrm{C}^{+}$, positive control; DHA, docosahexaenoic acid; QE, quercetin; COX-2, cyclooxygenase-2.

the combination of the two inhibits $\mathrm{NO}$ expression through scavenging $\mathrm{NO}$ as well as inhibiting the expression of iNOS.

Inhibitory effects of $Q E$ and DHA on the expression of inflammatory mediators. Pro-inflammatory cytokines are critical markers of inflammatory responses in LPS-stimulated macrophages. The concentration levels of IL-1 $\beta$, IL- 6 and TNF- $\alpha$ were examined using ELISA to evaluate the effects of DHA $(30 \mu \mathrm{M})$ and $\mathrm{QE}(20 \mu \mathrm{M})$ on cytokine production. The results indicated that $\mathrm{DHA}+\mathrm{QE}$ in combination exert a stronger inhibitory effect on cytokine production compared with DHA or $\mathrm{QE}$ alone $(\mathrm{P}<0.01$; Fig. $2 \mathrm{C}-\mathrm{E})$. All inhibitory effects were statistically significant and no enhancement of cytokine production was observed.

The production of PGE2, another important pro-inflammatory mediator, depends on COX-2 activity. The present study examined the effect of QE and DHA, and their cooperation, on PGE2 protein concentration and COX-2 protein expression. The results demonstrated that DHA and QE significantly decreased PGE2 concentration levels compared with the $\mathrm{C}^{+}$group $(\mathrm{P}<0.01)$. Whilst $\mathrm{QE}$ and DHA individually significantly inhibited PGE2 concentration levels, their use in combination further reduced PGE2 concentration compared with individual treatment $(\mathrm{P}<0.01$; Fig. $3 \mathrm{~A})$. Synergistic effects were determined using the Bliss model as $\mathrm{E}_{(\mathrm{AB})}(0.576)$ was less than $\mathrm{E}_{(\mathrm{A})} \times \mathrm{E}_{(\mathrm{B})}(0.632$; $\mathrm{DHA} \times \mathrm{QE}=0.752 \times 0.840)$. Similarly, COX-2 protein expression was significantly reduced in response to DHA + QE compared with individual treatments $\left[\mathrm{E}_{(\mathrm{AB})}=0.524 ; \mathrm{E}_{(\mathrm{A})} \times \mathrm{E}_{(\mathrm{B})}=0.706\right]$, which further confirms the synergistic effects of DHA and QE (Fig. 3B).

Effects of QE and DHA on the phosphorylation of key proteins in LPS-induced RAW264.7 cells. RAW264.7 cells were stimulated with LPS and incubated with DHA $(30 \mu \mathrm{M})$,
$\mathrm{QE}(20 \mu \mathrm{M})$ or DHA + QE for $24 \mathrm{~h}$. Phosphorylated protein expression levels were determined by western blot analysis. Assays indicated that the inhibitory effects of DHA+QE on p50, IкB and p65 phosphorylation were increased when used in combination compared with individual use (Fig. 4A and B). The phosphorylation levels of p50, p65 and I $\kappa$ B were also significantly increased following LPS induction (C+ group) in comparison with the $\mathrm{C}$ - group. Following individual treatment with QE and DHA, the phosphorylation levels of p50, p65 and I $\mathrm{B}$ were decreased compared with the $\mathrm{C}+$ group $(\mathrm{P}=0.01)$. However, phosphorylation decreased further to levels close to that in the C-group when cells were treated with DHA+QE in combination. Synergistic effect was observed when DHA and $\mathrm{QE}$ were combined to prevent the phosphorylation of p50 $\left[\mathrm{E}_{(\mathrm{AB})}=0.37 ; \mathrm{E}_{(\mathrm{A})} \times \mathrm{E}_{(\mathrm{B})}=0.46\right]$ and p65 $\left[\mathrm{E}_{(\mathrm{AB})}=0.48 ; \mathrm{E}_{(\mathrm{A})} \mathrm{x}\right.$ $\left.\mathrm{E}_{(\mathrm{B})}=0.42\right]$. By contrast, stimulation with LPS $\left(\mathrm{C}^{+}\right.$group) significantly decreased the expression of IKB protein in comparison with the $\mathrm{C}^{-}$group. I $\mathrm{B}$ degradation was significantly inhibited by DHA+QE. Furthermore, the effect of the drugs in combination was greater then their individual use (Fig. 4C). According to the Bliss model, an additive effect was detected when the drugs combined $\left[\mathrm{E}_{(\mathrm{AB})}=0.30 ; \mathrm{E}_{(\mathrm{A})} \times \mathrm{E}_{(\mathrm{B})}=0.30\right.$ ). These findings suggest that $\mathrm{I} \kappa \mathrm{B}$ degradation and phosphorylation are inhibited by DHA and QE.

The MAPK pathways are involved in the excess production of pro-inflammatory cytokines during inflammation and activate NF- $\kappa B$ in LPS-induced macrophages (2). The effect of QE and DHA on LPS-stimulated phosphorylation of ERK, JNK and p38MAPK in RAW264.7 cells was examined to evaluate whether these molecules counteract the effects of LPS at the molecular level. LPS treatment $\left(\mathrm{C}^{+}\right.$group) significantly increased the phosphorylation of ERK, JNK and p38MAPK. DHA and QE, alone and in combination, reduced the phosphorylation of the MAPK pathway proteins compared with 
A

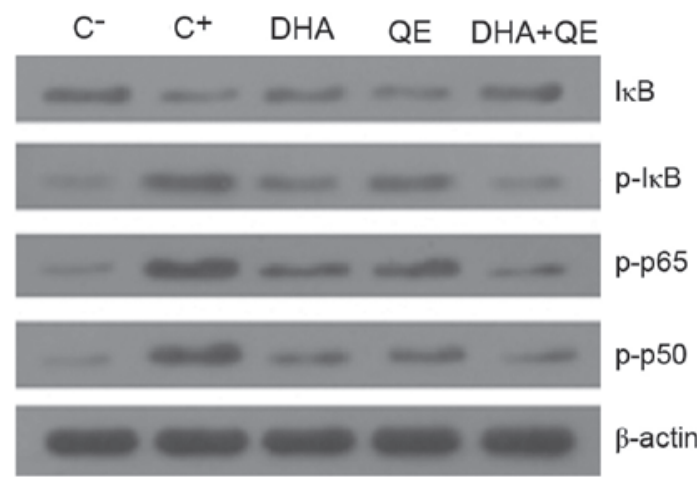

B
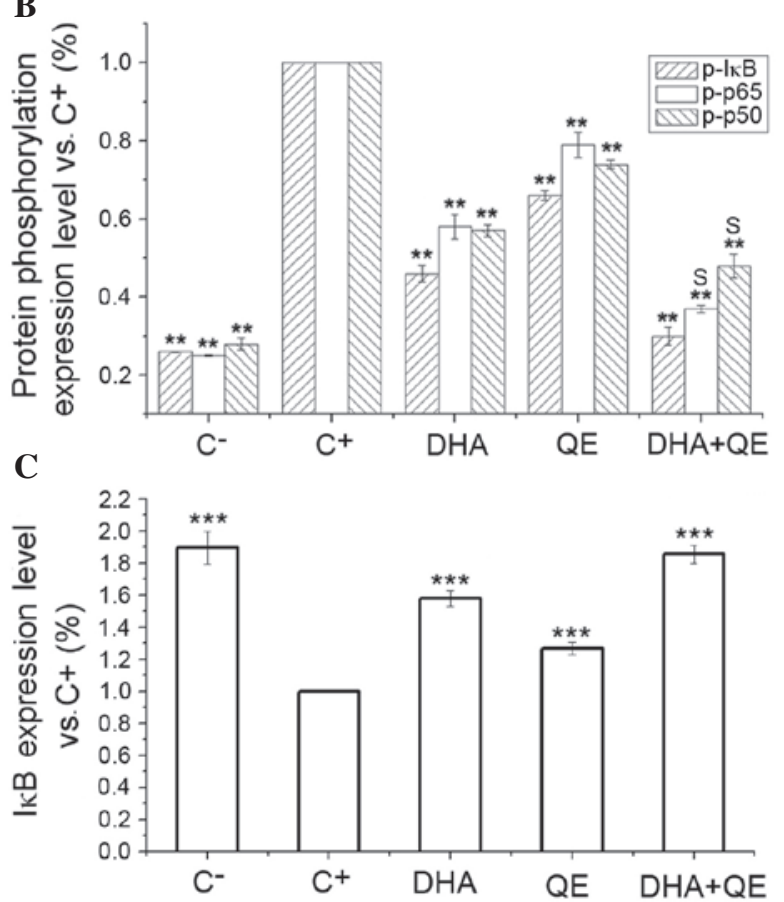

Figure 4. Effects of DHA and QE on IkB, p50 and p65 phosphorylation and IкB degradation in lipopolysaccharide (LPS)-induced RAW264.7 cells RAW264.7 cells were stimulated with LPS $(100 \mathrm{ng} / \mathrm{ml})$ and incubated with DHA $(30 \mu \mathrm{M}), \mathrm{QE}(20 \mu \mathrm{M})$ or $\mathrm{QE}+\mathrm{DHA}$ for $24 \mathrm{~h}$. (A) The protein expres-

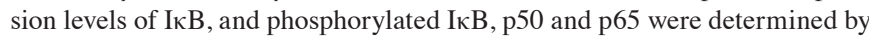
western blot analysis. (B and C) Levels were quantified using densitometry and each signal was normalized to the $\beta$-actin signal. Results are expressed as percentages relative to the $\mathrm{C}^{+}$group. Values are presented as the mean \pm standard deviation of biological and technical triplicates. ${ }^{* *} \mathrm{P}<0.01$ and ${ }^{* * * *} \mathrm{P}<0.001$ vs. $\mathrm{C}^{+}$group. Synergistic effects are indicated by the letter S. $\mathrm{C}^{-}$, negative control; $\mathrm{C}^{+}$, positive control; DHA, docosahexaenoic acid; QE, quercetin; ІкB, inhibitor of nuclear factor-кB; p-, phospho-

LPS stimulation $\left(\mathrm{C}^{+}\right.$group; $\left.\mathrm{P}<0.01\right)$. The effect of $\mathrm{DHA}+\mathrm{QE}$ treatment was more potent compared with $\mathrm{QE}$ or DHA alone. Synergistic effects on ERK $\left[\mathrm{E}_{(\mathrm{AB})}=0.694 ; \mathrm{E}_{(\mathrm{A})} \times \mathrm{E}_{(\mathrm{B})}=0.760\right]$ and JNK $\left[\mathrm{E}_{(\mathrm{AB})}=0.628 ; \mathrm{E}_{(\mathrm{A})} \times \mathrm{E}_{(\mathrm{B})}=0.665\right]$ phosphorylation were detected when $\mathrm{QE}+\mathrm{DHA}$ were used in combination However, the combination exhibited an antagonistic effect on p38 expression $\left[\mathrm{E}_{(\mathrm{AB})}=0.401 ; \mathrm{E}_{(\mathrm{A})} \times \mathrm{E}_{(\mathrm{B})}=0.424\right]$ according to the Bliss model (Fig. 5).

Effects of DHA and QE on the MRNA expression of key genes in LPS-induced RAW264.7 cells. RAW264.7 cells were stimulated with LPS $(100 \mathrm{ng} / \mathrm{ml})$ for $24 \mathrm{~h}$ to induce the expression

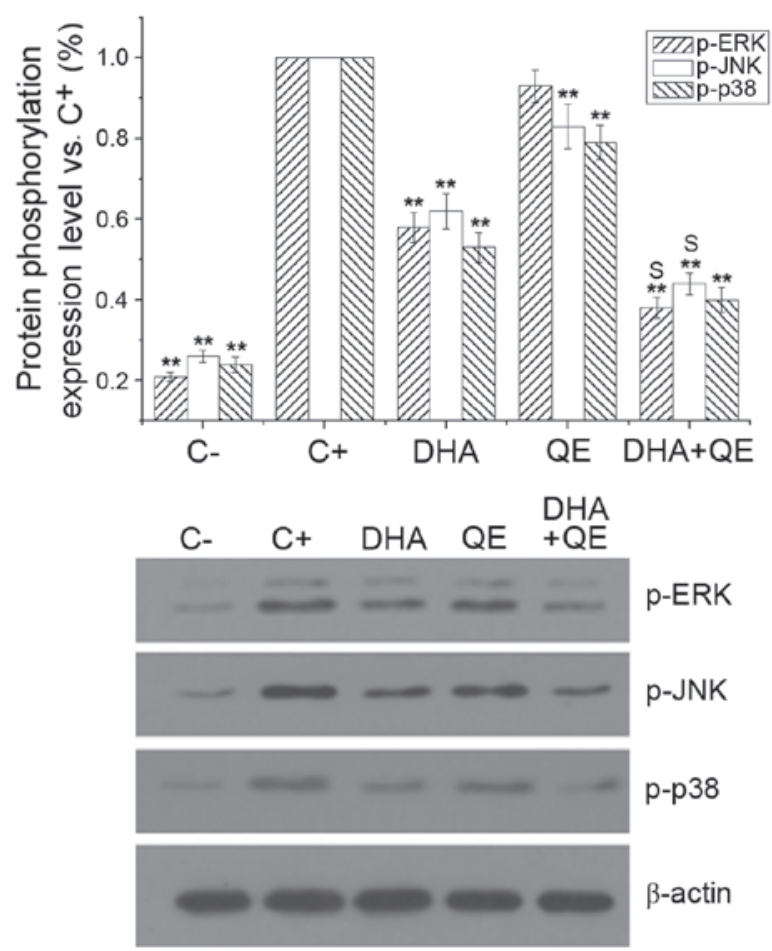

Figure 5. Effects of QE and DHA on ERK, JNK and p38MAPK phosphorylation levels in lipopolysaccharide (LPS)-induced RAW264.7 cells. RAW264.7 cells were stimulated with LPS $(100 \mathrm{ng} / \mathrm{ml})$ and incubated with DHA $(30 \mu \mathrm{M}) \mathrm{QE}(20 \mu \mathrm{M})$ or DHA + QE for $24 \mathrm{~h}$. Phosphorylation levels of ERK, JNK and p38MAPK were determined by western blot analysis, and each signal was normalized to the $\beta$-actin signal. Results are expressed as percentages of the $\mathrm{C}^{+}$group. Values are presented as the mean \pm standard deviation of biological and technical triplicates. ${ }^{* *} \mathrm{P}<0.01$ vs. $\mathrm{C}^{+}$group. Synergistic effects are indicated by the letter $\mathrm{S} . \mathrm{C}^{-}$, negative control; $\mathrm{C}^{+}$, positive control; $\mathrm{QE}$, quercetin; DHA, docosahexaenoic acid; p-, phospho-; ERK, extracellular signal-regulated kinase; JNK, c-JUN N-terminal kinase.

of genes regulating important proteins involved in the NF- $\kappa \mathrm{B}$ and MAPK signalling pathways. Cells were then treated with DHA $(30 \mu \mathrm{M}), \mathrm{QE}(20 \mu \mathrm{M})$ or DHA + QE to determine the effect of these molecules on I $\kappa$ B, p65, p50, ERK1/2, JNK and p38MAPK mRNA expression (Fig. 6). mRNA expression levels that exhibited significant differences compared with the $\mathrm{C}^{+}$group were considered upregulated or downregulated, respectively. RT-PCR demonstrated that p50, p65 (Fig. 6A), p38MAPK, ERK1/2 and JNK1/2 mRNA expression levels (Fig. 6B) were significantly increased in the $\mathrm{C}^{+}$group compared with the $\mathrm{C}^{-}$group. Individual QE or DHA treatment has no effect on the mRNA expression levels of these genes, however the combined use of DHA and QE significantly reduced the mRNA expression of p50, p65, p38MAPK, ERK1/2 and JNK compared with the $\mathrm{C}^{+}$group treatment. However, according to the criterion of the mathematical model mentioned above, the combination was considered to have no effect. By contrast, LPS stimulation $\left(\mathrm{C}^{+}\right.$group) decreased the mRNA expression of I $\mathrm{KB}$ in comparison with the $\mathrm{C}^{-}$group, and DHA or QE treatment increased the I $\kappa \mathrm{B}$ levels (Fig. 6A). The DHA+QE combined treatment resulted in a stronger upregulation of ІкB mRNA expression compared with either compound alone. Similarly, according to the criterion of the mathematical model mentioned above, the combination was considered to have no effect. This result may demonstrate that the inhibitory 
A

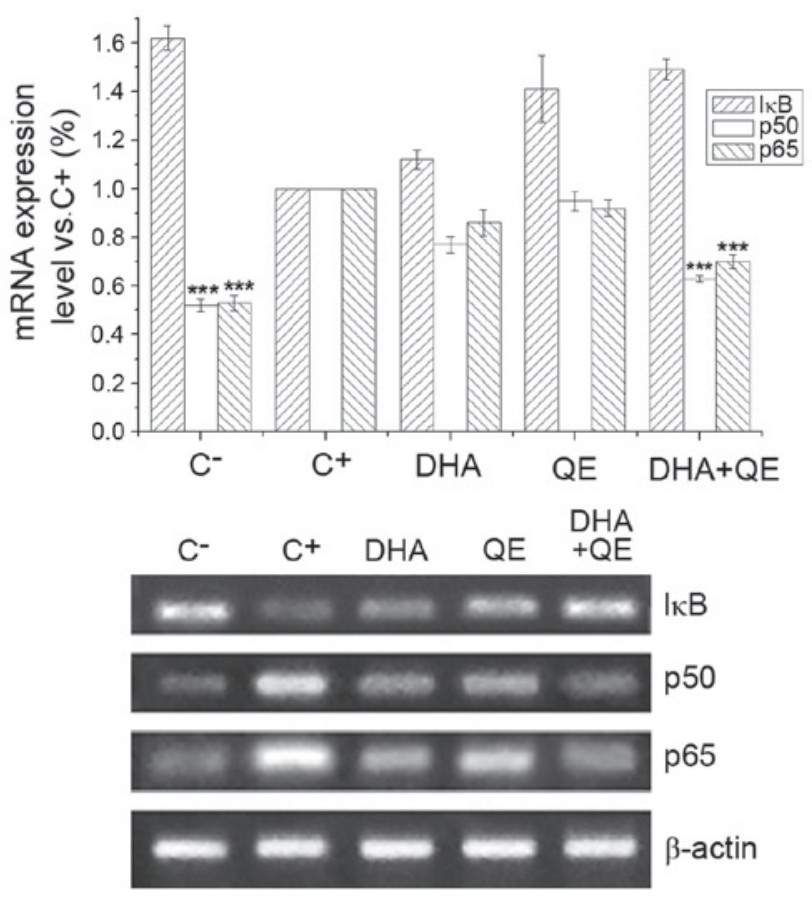

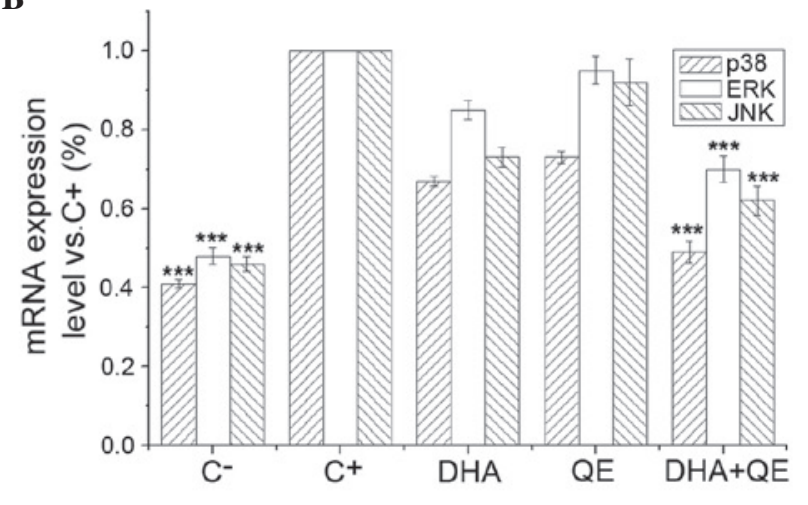

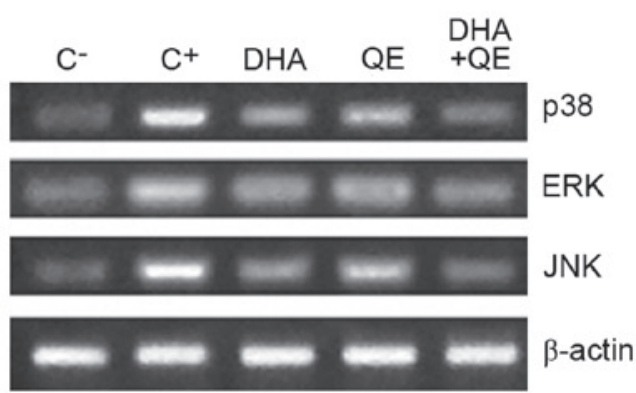

Figure 6. Effects of DHA and QE on IкB, p65, p50, ERK1/2, JNK1/2 and p38MAPK mRNA expression levels. RAW264.7 cells were stimulated with lipopolysaccharide (LPS) and incubated with DHA (30 $\mu \mathrm{M}), \mathrm{QE}(20 \mu \mathrm{M})$ or DHA + QE for 20 h. mRNA expression levels of (A) I $\mathrm{B}$, p65, p50, (B) ERK1/2, JNK1/2 and p38MAPK were determined by reverse transcription-polymerase chain reaction. Results are expressed as percentages of the $\mathrm{C}^{+}$group. Values are presented as the mean \pm standard deviation of biological and technical triplicates. ${ }^{* * *} \mathrm{P}<0.001$ vs. $\mathrm{C}^{+}$group. $\mathrm{C}^{-}$, negative control; $\mathrm{C}^{+}$, positive control;

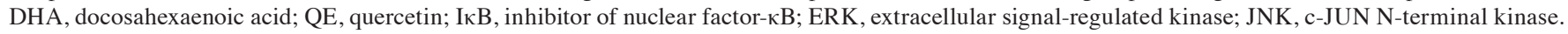

effect on NF- $\kappa \mathrm{B}$ and MAPK was through inhibiting the phosphorylation of p50, p65, IкB, p38MAPK, ERK1/2 and JNK, which involves NF- $\kappa \mathrm{B}$ and MAPK.

\section{Discussion}

Understanding the advantageous effects of bioactive compounds, and using this knowledge to improve and produce more health-beneficial foods, is an important field in functional food science $(19,20)$. Such compounds can be investigated using in vitro and in vivo models. The present study presents initial in vitro experiments using two natural bioactive molecules.

RAW264.7 murine macrophages are a commonly used cell line for investigating inflammation due to their reproducible response to LPS stimulation (19). In the present study, murine RAW264.7 macrophages were stimulated with LPS to induce an inflammatory response, and investigate the anti-inflammatory effects of DHA and QE. The LPS concentration used in the current study was lower and less aggressive than concentrations used in previous studies $(1$ or $10 \mu \mathrm{g} / \mathrm{ml})(21,22)$. The LPS concentration used herein was more appropriate for investigating the anti-inflammatory effects of QE and DHA, as previous studies indicate that $100 \mathrm{ng} / \mathrm{ml}$ LPS induces inflammation in macrophages at a level that is sensitive to the anti-inflammatory effects of DHA $(18,23)$. As natural nutrients, the anti-inflammatory activity of DHA and QE are less potent than those of other pharmaceutical agents, therefore, the present study focused on anti-inflammatory compound sensitivity at low levels of LPS stimulation. A previous study reported that 48 subjects who consumed fish once or twice a week presented plasma DHA and EPA levels of $\sim 60$ and $10 \mu \mathrm{g} / \mathrm{ml}$, or $\sim 182$ and $33 \mu \mathrm{M}$, respectively (24). Thus, the DHA concentration used in the present study is within the ranges of bioavailable levels observed in plasma during previous in vivo studies. The functions of QE, particularly its anti-inflammatory and anti-obesity properties, have been extensively investigated. The effects of QE in mice are well established, however, the activity in human subjects is unclear (22). Poor in vivo results using QE may be attributed to the limited aqueous solubility, stability and cellular bioavailability of the compound (25). QE concentrations in human plasma are generally in the low nanomolar range but may increase to the micromolar range by supplementation (26). Several in vitro studies have previously demonstrated that the anti-inflammatory and antioxidant capacities of QE at concentrations of 2.5-100 $\mu \mathrm{M}$ are time- and dose-dependent. Improved QE bioavailability has also been observed through nano-crystallisation $(22,25)$. Thus, the concentrations of QE and DHA used in the present study were selected based on previous in vitro and in vivo models.

The aim of the present study was to evaluate the anti-inflammatory effects of DHA and QE individually and in combination. Previous studies demonstrated that QE has anti-inflammatory effects in vitro and in vivo, and that $\mathrm{QE}$ can suppress LPS-induced production of pro-inflammatory cytokines (NO, PGE2, TNF- $\alpha$, IL-1 $\beta$ and IL-6), modulate iNOS and COX-2 synthesis, inhibit IкB kinase $\alpha$ and $\beta$, and stimulate IL-10 secretion and heme oxygenase-1 (HO-1) induction. QE has also be reported to inhibit NF-кB, MAPKs, protein kinase B, Src, Janus kinase 1, tyrosine kinase 2, and 
signal transducer and activator of transcription $1(27,28)$. The mechanisms of these health-promoting effects are associated with QE regulation of several important enzymes, cytokines, transcription factors and antioxidant systems (29). DHA or fish oil can modulate anti-inflammatory processes in macrophages through G-protein-coupled receptors (GPR120 pathway), and regulate inflammatory gene expression through decreased activation of $\mathrm{NF}-\kappa \mathrm{B}$ and increased activation of peroxisome proliferator-activated receptor- $\gamma$ (30-32). In the present study, $\mathrm{QE}$ and DHA individually reduced the levels of LPS-induced NO, iNOS, COX-2, PGE2 and cytokines (IL-1 $\beta$, IL-6 and TNF- $\alpha$ ), and synergistic inhibitory effects on NO, COX-2 and PGE2 levels were observed when these molecules were combined. The findings of the present study suggest that QE and DHA can inhibit the production of a variety of inflammatory mediators. In particular, their use in combination demonstrated significantly enhanced suppression of inflammatory mediators compared with either compound alone. This result may be attributed to the potency of DHA and QE as anti-inflammatory agents, and their combination can affect a greater number of proteins involved in signalling pathways to achieve enhanced anti-inflammatory effects. Although understanding of the anti-inflammatory mechanisms of action of QE and DHA in LPS-induced RAW264.7 cells is limited, previous studies report that $\mathrm{QE}$ and DHA diminish NO and PGE2 production via inhibition of iNOS and COX-2 protein expression $(11,18)$. Previous research has consistently demonstrated that DHA and QE decrease the production of inflammatory cytokines (IL-1 $\beta$, IL- $6, \mathrm{TNF}-\alpha$ ) and reduce their mRNA expression $(16,20,28)$. Although the present study demonstrated that DHA and QE mediate anti-inflammatory effects via proteins involved in the NF- $\mathrm{NB}$ signalling pathway, further research is necessary to determine whether the potential differential effects of DHA and QE occur upstream of NF- $\mathrm{B}$. The inhibitory effect of DHA and QE on the phosphorylation levels of p65, I $\mathrm{B}$ and p50 was enhanced when the compounds were used in combination. Previous reports and the present study demonstrate that effect DHA/QE on NF- $\kappa \mathrm{B}$ signalling in macrophages is exerted by preventing LPS-induced phosphorylation of I $\mathrm{KB}$ and p65 $(23,33)$. In the present study, suppression of LPS-induced NF- $\kappa \mathrm{B}$ signalling was also observed at the mRNA level, as DHA and QE combined treatment significantly reduced the mRNA expression levels of p50 and $\mathrm{p} 65$. This finding demonstrates that DHA and QE reduce $\mathrm{NF}-\kappa \mathrm{B}$ activation in LPS-induced macrophages.

MAPK proteins, which are activated by LPS in various cell lines, are comprised of three subfamilies (ERK1/2, JNK1/2 and p38MAPKs), and are involved in LPS-stimulated iNOS and COX-2 expression in macrophages. Activated MAPKs also regulate the phosphorylation of numerous important signalling molecules mediating cell inflammation, proliferation and apoptosis (34-36). Combined DHA + QE treatment exerted a stronger inhibitory effect on the phosphorylation levels of MAPK proteins compared with DHA or QE alone. Whilst DHA alone markedly reduced the LPS-induced phosphorylation of ERK, JNK and p38MAPK, QE alone did not markedly inhibit ERK phosphorylation. Several studies have demonstrated that DHA can modulate the MAPK signalling pathway in LPS-stimulated macrophages $(37,38)$. A previous investigation indicated that QE can inhibit ERK1/2 and p38MAPK activation, but not JNK, in LPS-induced RAW264.7 cells (39). However, another study demonstrated that QE can suppress p38MAPK and JNK but not ERK1/2 activation; this study also observed that iNOS, COX-2 and HO-1 induction were suppressed by a p38 and JNK1/2 inhibitor but not an ERK inhibitor. The aforementioned findings suggest that JNK and p38MAPK induce the activation of anti-inflammatory (HO-1) and pro-inflammatory (iNOS and COX-2) mediators in LPS-induced RAW264.7 cells (28). Thus, the results of the present study are in agreement with the previous findings, demonstrating that QE can effectively inhibit JNK and p38MAPK activation in the MAPK signalling pathway. The results of the present study demonstrate that DHA + QE treatment is effective, as this combination can modulate more pathways than DHA or QE individually. The synergistic effects of DHA and QE on the reduction of ERK and JNK phosphorylation may complement their synergistic effects on the suppression of NO, PGE2 and COX-2 levels. Previous reports demonstrate that activated $\mathrm{NF}-\kappa \mathrm{B}$ has a half-life of $<30 \mathrm{~min}$. Thus, maintenance of $\mathrm{NF}-\kappa \mathrm{B}$ activity depends on continuous transcription and protein synthesis of the genes encoding NF- $\kappa \mathrm{B}$ proteins (40). The results of the present study indicate that $\mathrm{QE}+\mathrm{DHA}$ in combination significantly decrease the mRNA expression levels of p50, p65, JNK and ERK1/2, thus, inhibiting the inflammatory response.

In conclusion, combining DHA $(30 \mu \mathrm{M})$ and $\mathrm{QE}(20 \mu \mathrm{M})$ treatment enhances their anti-inflammatory effects in LPS-induced RAW264.7 macrophages by decreasing the levels of inflammatory mediators (NO, PGE2, iNOS and COX-2) and inflammatory cytokines (IL-1 $\beta$, IL- 6 and TNF- $\alpha$ ). This combination also exerts an enhanced effect on the expression and phosphorylation of NF- $\mathrm{NB}$ and MAPK signalling pathway proteins compared with their effects individually. Future studies should investigate the anti-inflammatory effects of different $\mathrm{QE}$ and DHA doses in combination, as well as the use of the Loewe method to calculate synergistic effects. Since the synergistic, additive and antagonistic effect can be determined using different models, such as the Loewe model, this may be useful to conduct in future studies. The present study provides insight into the benefits of foods and beverages containing these molecules. The findings of the current study should be investigated further in future in vivo studies by examining QE and DHA as nutritional supplements to exert preventative or palliative effects on obesity, atherosclerosis and cardiovascular diseases. The potential mechanisms of the anti-inflammatory effects of DHA and QE in LPS-stimulated RAW264.7 cells are summarized in Fig. 7.

\section{Acknowledgements}

The present study was supported by the Fundamental Research Funds for the Central Universities (nos. 2013PY098 and 2014PY011).

\section{References}

1. Lorente-Cebrián S, Costa AG, Navas-Carretero S, Zabala M, Martínez JA and Moreno-Aliaga MJ: Role of omega-3 fatty acids in obesity, metabolic syndrome, and cardiovascular diseases: A review of the evidence. J Physiol Biochem 69: 633-651, 2013. 
2. Yang D, Lin J, Chen Y, Liu S, Lu F, Chang T, Wang M, Lin H and Chang Y: Suppressive effect of carotenoid extract of Dunaliella salina alga on production of LPS-stimulated pro-inflammatory mediators in RAW264.7 cells via NF-kB and JNK inactivation. J Funct Foods 5: 607-615, 2013.

3. Pan MH, Lai CS and Ho CT: Anti-inflammatory activity of natural dietary flavonoids. Food Funct 1: 15-31, 2010.

4. Hsu CL, Fang SC and Yen GC: Anti-inflammatory effects of phenolic compounds isolated from the flowers of Nymphaea mexicana Zucc. Food Funct 4: 1216-1222, 2013

5. Huang N, Hauck C, Yum MY, Rizshsky L, Widrlechner MP, McCoy JA, Murphy PA, Dixon PM, Nikolau BJ and Birt DF: Rosmarinic acid in Prunella vulgaris ethanol extract inhibits lipopolysaccharide-induced prostaglandin E2 and nitric oxide in RAW 264.7 mouse macrophages. J Agric Food Chem 57: 10579-10589, 2009.

6. Lai C, Lai Y, Kuo D, Wu C, Ho C and Pan M: Magnolol potently suppressed lipopolysaccharide-induced iNOS and COX-2 expression via downregulating MAPK and NF- $\kappa \mathrm{B}$ signaling pathways. J Funct 3: 198-206, 2011.

7. Chiu FL and Lin JK: Tomatidine inhibits iNOS and COX-2 through suppression of $\mathrm{NF}-\kappa \mathrm{B}$ and JNK pathways in LPS-stimulated mouse macrophages. FEBS Lett 582: 2407-2412, 2008

8. Kim KJ, Yoon KY and Lee BY: Low molecular weight fucoidan from the sporophyll of Undaria pinnatifida suppresses inflammation by promoting the inhibition of mitogen-activated protein kinases and oxidative stress in RAW264.7 cells. Fitoterapia 83: $1628-1635,2012$

9. Avior Y, Bomze D, Ramon O and Nahmias Y: Flavonoids as dietary regulators of nuclear receptor activity. Food Funct 4: 831-844, 2013

10. Ahn J, Lee H, Kim S, Park J and Ha T: The anti-obesity effect of quercetin is mediated by the AMPK and MAPK signaling pathways. Biochem Biophys Res Commun 373: 545-549, 2008

11. Lin HY, Juan SH, Shen SC, Hsu FL and Chen YC; Inhibition of lipopolysaccharide-induced nitric oxide production by flavonoids in RAW264.7 macrophages involves heme oxygenase-1. Biochem Pharmacol 66: 1821-1832, 2003.

12. Chow JM, Shen SC, Huan SK, Lin HY and Chen YC: Quercetin, but not rutin and quercitrin, prevention of $\mathrm{H}_{2} \mathrm{O}_{2}$-induced apoptosis via anti-oxidant activity and heme oxygenase 1 gene expression in macrophages. Biochem Pharmacol 69: 1839-1851, 2005.

13. Strobel P, Allard C, Perez-Acle T, Calderon R, Aldunate R and Leighton F: Myricetin, quercetin and catechin-gallate inhibit glucose uptake in isolated rat adipocytes. Biochem J 386: 471-478, 2005.

14. Das N, Sikder K, Bhattacharjee S, Majumdar SB, Ghosh S, Majumdar S and Dey S: Quercetin alleviates inflammation after short-term treatment in high-fat-fed mice. Food Funct 4 : 889-898, 2013

15. Firdous AB, Sharmila G, Balakrishnan S, RajaSingh P Suganya S, Srinivasan N and Arunakaran J: Quercetin, a natural dietary flavonoid, acts as a chemopreventive agent against prostate cancer in an in vivo model by inhibiting the EGFR signaling pathway. Food Funct 5: 2632-2645, 2014.

16. Pallarès V, Calay D, Cedó L, Castell-Auví A, Raes M, Pinent M, Ardévol A, Arola L and Blay M: Enhanced anti-inflammatory effect of resveratrol and EPA in treated endotoxin-activated RAW 264.7 macrophages. Br J Nutr 108: 1562-1573, 2012.

17. Venegas-Calerón M, Sayanova O and Napier JA: An alternative to fish oils: Metabolic engineering of oil-seed crops to produce omega-3 long chain polyunsaturated fatty acids. Prog Lipid Res 49: 108-119, 2010.

18. Mullen A, Loscher CE and Roche H: Anti-inflammatory effects of EPA and DHA are dependent upon time and dose-response elements associated with LPS stimulation in THP-1-derived macrophages. J Nutr Biochem 21: 444-450, 2010.

19. Pallarès V, Calay D, Cedó L, Castell-Auví A, Raes M, Pinent M, Ardévol A, Arola L and Blay M: Additive, antagonistic, and synergistic effects of procyanidins and polyunsaturated fatty acids over inflammation in RAW 264.7 macrophages activated by lipopolysaccharide. Nutrition 28: 447-457, 2012.
20. Choi EY, Jin JY, Choi JI, Choi IS and Kim SJ: DHA suppresses Prevotella intermedia lipopolysaccharide-induced production of proinflammatory mediators in murine macrophages. Br J Nutr 111: 1221-1230, 2014.

21. Manjeet KR and Ghosh B: Quercetin inhibits LPS-induced nitric oxide and tumor necrosis factor- $\alpha$ production in murine macrophages. Int J Immunopharmacol 21: 435-443, 1999.

22. Boots AW, Haenen GR and Bast A: Health effects of quercetin: From antioxidant to nutraceutical. Eur J Pharmacol 585: 325-337, 2008.

23. Saw CL, Huang Y and Kong AN: Synergistic anti-inflammatory effects of low doses of curcumin in combination with polyunsaturated fatty acids: Docosahexaenoic acid or eicosapentaenoic acid. Biochem Pharmacol 79: 421-430, 2010.

24. Rusca A, Di Stefano AF, Doig MV, Scarsi C and Perucca E: Relative bioavailability and pharmacokinetics of two oral formulations of docosahexaenoic acid/eicosapentaenoic acid after multiple-dose administration in healthy volunteers. Eur J Clin Pharmacol 65: 503-510, 2009.

25. Leiherer A, Mündlein A and Drexel H: Phytochemicals and their impact on adipose tissue inflammation and diabetes. Vascul Pharmacol 58: 3-20, 2013

26. Sun M, Nie S, Pan X, Zhang R, Fan Z, Wang S: Quercetin-nanostructured lipid carriers: Characteristics and anti-breast cancer activities in vitro. Colloids Surf Biointerfaces 113: 15-24, 2014.

27. Russo M, Spagnuolo C, Tedesco I, Bilotto S and Russo GL: The flavonoid quercetin in disease prevention and therapy: Facts and fancies. Biochem Pharmacol 83: 6-15, 2012.

28. Endale M, Park SC, Kim S, Kim SH, Yang Y, Cho JY and Rhee MH: Quercetin disrupts tyrosine-phosphorylated phosphatidylinositol 3-kinase and myeloid differentiation factor-88 association, and inhibits MAPK/AP-1 and IKK/NF- $\mathrm{kB}$-induced inflammatory mediators production in RAW 264.7 cells. Immunobiology 218: 1452-1467, 2013

29. Gomes A, Fernandes E, Lima JL, Mira L and Corvo ML: Molecular mechanisms of anti-inflammatory activity mediated by flavonoids. Curr Med Chem 15: 1586-1605, 2008.

30. Kalupahana NS, Claycombe KJ and Moustaid-Moussa N: (n-3) Fatty acids alleviate adipose tissue inflammation and insulin resistance: Mechanistic insights. Adv Nutr 2: 304-316, 2011

31. Oh DY, Talukdar S, Bae EJ, Imamura T, Morinaga H, Fan W, Li P, Lu WJ, Watkins SM and Olefsky JM: GPR120 is an omega-3 fatty acid receptor mediating potent anti-inflammatory and insulin-sensitizing effects. Cell 142: 687-698, 2010

32. Wall R, Ross RP, Fitzgerald GF and Stanton C: Fatty acids from fish: The anti-inflammatory potential of long-chain omega-3 fatty acids. Nutr Rev 68: 280-289, 2010.

33. Peet GW and Li J: I $\kappa B$ Kinases $\alpha$ and $\beta$ show a random sequential kinetic mechanism and are inhibited by staurosporine and quercetin. J Biol Chem 274: 32655-32661, 1999.

34. Feng D, Ling WH and Duan RD: Lycopene suppresses LPS-induced NO and IL-6 production by inhibiting the activation of ERK, p38MAPK, and NF-kappaB in macrophages. Inflamm Res 59: 115-121, 2010.

35. Blüthgen N and Legewie S: Systems analysis of MAPK signal transduction. Essays Biochem 45: 95-107, 2008.

36. Turjanski AG, Vaqué JP and Gutkind JS: MAP kinases and the control of nuclear events. Oncogene 26: 3240-3253, 2007.

37. Lo CJ, Chiu KC, Fu M, Chu A and Helton S: Fish oil modulates macrophage P44/P42 mitogen-activated protein kinase activity induced by lipopolysaccharide. JPEN J Parenter Enteral Nutr 24: 159-163, 2000.

38. Moon Y and PestkaJJ: Deoxynivalenol-induced mitogen-activated protein kinase phosphorylation and IL-6 expression in mice suppressed by fish oil. J Nutr Biochem 14: 717-726, 2003.

39. Cho SY, Park SJ, Kwon MJ, Jeong TS, Bok SH, Choi WY, Jeong WI, Ryu SY, Do SH, Lee CS, et al: Quercetin suppresses proinflammatory cytokines production through MAP kinases and NF-kappaB pathway in lipopolysaccharide-stimulated macrophage. Mol Cell Biochem 243: 153-160, 2003.

40. Hohmann HP, Remy R, Scheidereit C and van Loon AP: Maintenance of NF-kappa B activity is dependent on protein synthesis and the continuous presence of external stimuli. Mol Cell Biol 11: 259-266, 1991. 